\title{
Emerging DNA Technologies and Stigmatization
}

\begin{abstract}
Despite their consolidated role in providing evidence for criminal justice, DNA technologies have been subjected to continuous investment that has given rise to the emergence of new DNA technologies. This chapter will focus on such innovations, explaining how forensic genetics is increasingly expanding its role in the criminal justice system. Recent technologies such as familial searching and forensic DNA phenotyping might help to generate intelligence for criminal investigations. Familial searching is a technology that attempts to identify criminal suspects through their genetic connection with relatives. Forensic DNA phenotyping makes it possible to focus on a particular suspect group that shares genetic ancestry and/or externally visible characteristics. The chapter critically reviews the existing debate in the field of social sciences about emerging DNA technologies. The core argument is that the application of DNA phenotyping and familial searching in the governance of crime holds the potential to increase risks of stigmatization and reinforce the criminalization of certain populations who are more vulnerable to the actions of the criminal justice system.
\end{abstract}

Keywords Intelligence $\bullet$ Familial searching • Forensic DNA phenotyping $\bullet$ Stigmatization $\bullet$ Criminalization

(C) The Author(s) 2020 


\section{From Evidence Towards Intelligence}

Since the establishment of the use of DNA technologies to support the activities in criminal justice systems worldwide, there has been an expansion in the breadth and reach of the potential ways they can be used. The applications of DNA technologies in the field of criminal justice systems include expanding the collection, storage and use of DNA profiles in forensic DNA databases (as covered in Chap. 5), the development of the exchange of DNA data among different countries within the context of police and judicial cooperation (see Chap. 6) and the speculative generation of criminal suspects based on information provided by DNA profiles - the topic which will form the basis for this chapter. In particular, this chapter addresses two emerging technologies in the field of forensic genetics: familial searching and forensic DNA phenotyping. The first refers to searches conducted in DNA databases to identify criminal suspects through their connection with relatives. Forensic DNA phenotyping is a set of techniques that allow inferring genetic ancestry and externally visible characteristics of criminal suspects on the basis of a DNA sample.

The ongoing development of these emergent DNA technologies represents a historical change in the presence of forensic genetic technologies in the criminal justice system. Firstly, because it shifts the focus of forensic science from the construction of evidence towards the generation of intelligence valuable to criminal investigations (Wienroth, 2018a). Secondly, such emergent DNA technologies move the locus from individualization, that is, identification of specific individuals, towards collectivization. It does so by clustering "suspect" populations which share biological links, genetic ancestry and/or externally visible characteristics. It is a process which the sociologist Simon Cole describes as the "convergence of individual and collective identification" (Cole, 2018, p. 2).

\section{Familial Searching in Forensic DNA Databases}

Familial searching is a term ${ }^{1}$ generally refers to searches conducted in forensic DNA databases to identify criminal suspects using their genetic connection to biological relatives (Debus-Sherrill \& Field, 2019; Granja \& Machado, 2019; Haimes, 2006; Kim, Mammo, Siegel, \& Katsanis,

\footnotetext{
${ }^{1}$ Other authors have proposed terms such as "low stringency search" (Gabel, 2010) or "genetic proximity testing" (Prainsack, 2010, p. 29) to describe this investigative technique.
} 
2011; Suter, 2010). Therefore, familial searching usually refers to a process through which a DNA profile that does not match any other profile contained in a criminal DNA database is subjected to a new analysis, in order to determine whether there are close matches. If such partial matches exist, it is probable that the profile obtained at the crime scene or from the victim(s) belongs to a close relative of the person in the database-usually parents, children or siblings.

One variation of such searches may occur when relatives of potential suspects are found among the DNA profiles collected by intelligence-led DNA massive screenings (Thomas, 2006). Another variant of familial searching might also occur when investigators find an inadvertent partial match while looking for a perfect correspondence between a certain DNA profile and the biological material found at a crime scene (Murphy, 2010, p. 9) - what Sara Debus-Sherrill and Michael Field call "partial matching" (Debus-Sherrill \& Field, 2019). The term familial searching in this chapter aims to encapsulate all its variations.

Familial searching in forensic DNA databases was first implemented in the UK in 2002 (Haimes, 2006; Prainsack, 2010) and its use has been expanding to other countries. The Netherlands and France introduced legislation that allows the use of this investigative technique (Maguire, McCallum, Storey, \& Whitaker, 2014) and, more recently, Germany has also approved the use of familial searching in intelligence-led DNA massive screenings (Criminal Code of Conduct-StPO $\$ 81 \mathrm{~h}$ ). In other EU countries, the situation remains unclear, although there are records of criminal cases that involved the use of relatives' DNA to search for criminal suspects in countries such as Spain, Poland (Dettlaff-Kakol \& Pawlowski, 2002) and Italy (Jones, 2015). Nevertheless, familial searching remains unregulated in most EU countries.

Beyond Europe, familial searching in forensic DNA databases was formally adopted by New Zealand and prohibited in Australia and Canada (Flaus, 2013; Thomas, 2006). The same kind of differentiation is found in the US, where familial searching is not conducted on a national level. On March 2008, the FBI determined that individual states should determine familial searching regulations. Following this decision, California was the first state to implement a policy for familial searching in 2008, followed by the state of Colorado in 2009. In 2011, Virginia also approved regulations on familial DNA searches, followed by Texas. More recently, in 2017, New York State also approved the use of this investigative technique. In contrast, Maryland and Washington, DC, banned familial searching. 
Additionally, some states have implemented specific regulations permitting partial match disclosure, such as Arizona, Connecticut, Florida, Missouri, Nebraska, Nevada, Oregon, Washington State and Wyoming (Kim et al., 2011).

In countries where familial searching in forensic DNA databases is regulated, guidelines are typically restrictive and allow its use only in certain criminal cases which are considered serious and difficult to solve through other means (Chamberlain, 2012). For example, in the UK, familial searches conducted in the National DNA Database (NDNAD) are analysed according to a case-by-case approach and are dependent on permission from the Chairman of the NDNAD Strategy Board and, in some cases, from the victim (Maguire et al., 2014). Despite its restrictive use, such investigative techniques have thus far produced information that has helped to identify suspects, convict offenders and exonerate wrongfully convicted individuals, both in cold and in non-cold cases in several countries (Kim et al., 2011). Nevertheless, the use of familial searching in forensic databases is still full of legal, ethical and social controversies (Chamberlain, 2012; García, Crespillo, \& Yurrebaso, 2017; Haimes, 2006; Kim et al., 2011; Maguire et al., 2014; Murphy, 2010; Nuffield Council on Bioethics, 2007; Suter, 2010).

The academic and public debate around familial searching can be summarized as framed around three main dimensions: genetic privacy, information disclosure and reproduction of social inequalities. The first is related to how familial searching might constitute a "function creep" (Prainsack, 2010, pp. 28-30), inasmuch as it expands the reach of forensic databases to include, even if indirectly, other people who might never have had any direct contact with the criminal justice system (Bieber, Brenner, \& Lazer, 2006; Epstein, 2009; Flaus, 2013; Suter, 2010; Thomas, 2006). This potential involvement of innocent people implies that this investigative technique increases indirect genetic surveillance on a certain group of individuals - relatives of potential suspects - primarily on the basis of their genetic association with someone (Bieber et al., 2006; Greely, Riordan, Garrison, \& Mountain, 2006; Haimes, 2006; Kim et al., 2011; Lazer, 2008; Murphy, 2010). By extension, the expansion of the reach of forensic databases also fosters a debate about the rights and duties of the "genetic informant", that is, the person whose sample is a partial match with the crime scene sample and who, unintentionally, implicates family members in criminal investigations (Gabel, 2010; Murphy, 2010; Suter, 2010; Williams \& Johnson, 2006, p. 16). 
The second dimension concerns the latent risk of familial searching disclosing information. This might relate to either the absence or the existence of genetic relations (Haimes, 2006; Kim et al., 2011; Nuffield Council on Bioethics, 2007; Suter, 2010) and/or to the involvement with the criminal justice system that remained unknown to others.

The third dimension regards the broader social implications of familial searching, in particular its potential to reinforce dominant views about the alleged prevalence of criminality within certain families (Gabel, 2010, p. 21; Haimes, 2006) and/or to further amplify inequalities. When conducted in forensic DNA databases, this investigative technique searches for potential suspects on a pre-established pool that generally overrepresents certain groups and social categories that are most affected by the actions of the criminal justice system, such as racial and ethnic minorities (Chow-White \& Duster, 2011; Duster, 2003; Skinner, 2013). In this sense, familial searching might end up reproducing the criminalization of certain social groups (Bieber et al., 2006; Epstein, 2009; Flaus, 2013; Greely et al., 2006; Grimm, 2007; Kim et al., 2011; Lazer, 2008; Murphy, 2010; Suter, 2010; Thomas, 2006).

Despite the lively debate that familial searching has been fomenting over the years, there are scarce empirical studies on this topic. One of them entails a National Survey of CODIS Laboratories in the US about policies and practices, as well as professionals' perceptions, as they relate to familial searching (Debus-Sherrill \& Field, 2019). Results show that while perceptions over familial searching were generally positive, with most respondents $(87 \%)$ believing that familial searching has potential to assist investigations, laboratories still shared a number of concerns related to familial searching. In addition to resource issues, which were indicated as the main concern, $83 \%$ of respondents working in a lab that conducts familial searching reported concerns over challenges to civil liberties, compared to $30 \%$ of respondents working in labs that do not conduct such genetic technique (Debus-Sherrill \& Field, 2019).

To date, only one empirical study on the topic of familial searching is known to have been undertaken in Europe. Based on a comparative study between the uses of familial searching in the UK and Poland, Rafaela Granja and Helena Machado outline the variability of familial searching in terms of meanings, uses and regulations (Granja \& Machado, 2019). In the UK, familial searching is regulated by exceptionality and is mainly used for the identification of suspects in serious criminal cases. In Poland, familial searching is regulated within the framework of expanding the scope of 
its application to the search and/or identification of missing persons. This chapter thereby shows how familial searching prescribes particular notions of social risks, public good and the accountability of the state. The elements that coproduce the different ways of perceiving ethical controversies about familial searching carry with them the weight of sociohistorical and techno-political backgrounds, the influence of distinctive forms of state accountability as well as the contingent and circumstantial character of what each society considers the socially legitimate uses of genetic technologies (Granja \& Machado, 2019).

\section{Long-Range Familial Searches in Recreational DNA DATABASES}

The existing discussion on familial searching suffered a major turning point in 2018, following the aftermath of the Golden State Killer ${ }^{2}$ criminal investigation. In that case, criminal investigators used DNA from crime scenes and uploaded the genetic information into an online public-access DNA database, GEDmatch. ${ }^{3}$ Based on that search, officers found partial matches with the profile of the presumed suspect, which were assumed to belong to distant relatives. Following up the partial match, family trees were built upon the basis of several other sources (social media and other types of online records) and Joseph James DeAngelo, 72 years old, was identified as a suspect and his "abandoned" DNA ${ }^{4}$ was collected to conduct further analysis. The result of the tests confirmed it matched the crime scene samples. ${ }^{5}$

\footnotetext{
${ }^{2}$ The Golden State Killer is the name coined by Michelle McNamara to refer to a serial killer and rapist who committed at least 12 murders, and more than 50 rapes in California, USA, from 1974 to 1986 . He is believed to be responsible for three crime sprees throughout California, each of which spawned a different nickname in the press (East Area Rapist and Original Night Stalker) before it became evident, through DNA analysis, that they were committed by the same person.

${ }^{3}$ GEDmatch is an online public-access database where individuals with data originated from different testing companies can compare their DNA with others on the database in order to trace relatives. More information here: https://www.gedmatch.com/loginl.php (last accessed 13 May 2019).

${ }^{4}$ In the US the police can collect "abandoned DNA", that is, a biological sample which has been left behind by the individual inadvertently or involuntarily, such as chewing gum or a tip of a cigarette. For a critical view of such procedures see Joh (2006).

${ }^{5}$ Writing dated from September 2019; the case is currently under trial.
} 
The Golden State Killer criminal case was not the first one using longrange familial cases to assist criminal investigations (Erlich, Shor, Pe'er, \& Carmi, 2018). However, since it became a widely discussed and highprofile criminal case, it completely reframed the discussion around the use of familial searching in criminal investigations. The case was considered by Nature one of the scientific events that shaped the year of 2018 (Abbott et al., 2018). Barbara Rae-Venter, a genealogist who helped to identify the Golden State Killer, was distinguished by the same journal as one of the "Ten people who mattered this year". According to Time, Barbara RaeVenter "has provided law enforcement with its most revolutionary tool since the advent of forensic DNA testing in the 1980s" (Holes, 2019).

The use of non-forensic DNA databases for criminal investigation purposes is not a new phenomenon. There are a few criminal cases where information stored, for example, in medical DNA databases was used to solve a criminal case. ${ }^{6}$ However, the Golden State Killer criminal case led to the first reports of recreational DNA databases being used in such enquiries. That is, databases held for commercial purposes-the so-called direct-to-consumer (DTC) genetic testing-to which citizens voluntarily upload their DNA in order to know about their ancestry and other genetic information, such as health issues (Abel, 2018; Borry, Cornel, \& Howard, 2010; Chow-White et al., 2018; Horowitz, Saperstein, Little, Maiers, \& Hollenbach, 2019).

In the aftermath of the Golden State Killer investigation, other criminal cases have been showing the increasing use of long-range familial searches in recreational DNA databases, with the purpose of accommodating the possibility of searching for criminal suspects. According to Erlich et al. (2018), between April and August 2018, 13 criminal cases in the US were solved through such searches. A significant portion of those had the involvement of Parabon NanoLabs, a company offering forensic services such as genetic genealogy, kinship inference and forensic DNA phenotyping (in this respect see also Wienroth, 2018a). In a more recent publication, members of the company refer to more than 30 law enforcement cases $^{7}$ solved by them and their collaborators, such as Barbara Rae-Venter and law enforcement agencies (Greytak, Moore, \& Armentrout, 2019).

${ }^{6}$ In Sweden, in 2003, forensic access to a medical biobank (PKU biobank-diagnostics) was authorized as part of the murder investigation of Anna Lindh (Swedish foreign minister).

${ }^{7}$ Through $31 / 1 / 19$. 
As a result, the use of long-range familial searches in recreational DNA databases has been the subject of highly visible public and regulatory controversy, posing new lines of enquiry on the uses of DNA data in the governance of crime. In the rest of this section, we will briefly summarize some of the topics under discussion.

Familial searching in forensic DNA databases uses autosomal short tandem repeats (STRs), the so-called junk genes that presumably hold little value other than for identification. Using that method, the investigative technique might, at best, identify close biological relatives (siblings, parents or children). In opposition, long-range familial searches in recreational DNA databases use single-nucleotide polymorphisms (SNPs), which are characterized by their informational richness (Greytak et al., 2019; Kennett, 2019; Murphy, 2018). ${ }^{8}$ As a result, that kind of use makes more informative data available to law enforcement, while also significantly expanding the network of people that might be affected by such procedures (Murphy, 2018). In this respect it is relevant to note that a study conducted by Yaniv Erlich and his colleagues estimates that "about $60 \%$ of the searches for individuals of European descent will result in a third cousin or a closer match, which can allow their identification using demographic identifiers" (Erlich et al., 2018). The use of long-range familial searches in recreational DNA databases thereby significantly expands the scope and impact of genetic surveillance.

Forensic DNA databases and recreational DNA databases also significantly differ in another aspect that has become increasingly relevant in the governance of crime. While the first tends to overrepresent the groups and social categories most affected by the actions of the criminal justice system, such as racial and ethnic minorities (Skinner, 2013), the latter is mainly composed of individuals with a North European genetic background (Erlich et al., 2018). This, therefore, implies that genetic surveillance is no longer restricted to the "management of those already deemed criminal" (Williams \& Johnson, 2004, p. 11): nowadays it also encapsulates individuals that might never have had contact with the criminal justice system before.

Another topic of discussion regarding long-range familial searches in recreational DNA databases relates to the lack of governance and over-

\footnotetext{
${ }^{8}$ In addition to this, since DTC companies obtain DNA from spit kits or cheek swabs, DNA profiles are always based on a large amount of high-quality single-source DNA. In opposition, forensic DNA samples might face several obstacles to an analysis by having only a small amount of degraded DNA and/or being mixed with DNA from other individuals (Greytak et al., 2019).
} 
sight. In the aftermath of the Golden State Killer criminal case, several private companies specialized in providing direct-to-consumer DNA tests and other online related resources updated their terms of use. However, due to the lack of regulatory norms, several companies in the market reacted differently. Some companies had decided to not allow uploads in their databases, stating that their data is not accessible to law enforcement unless a judicial request is made (Greytak et al., 2019; Kennett, 2019). However, the private company FamilyTreeDNA admitted in February 2019 that, without informing its users, it allowed the FBI to upload genetic profiles created from crime scenes and corpses. After the company's president, Bennett Greenspan, apologized for not revealing it sooner to its clients, the company produced a TV advertisement urging consumers to help them catch criminals. The television spot ${ }^{9}$ asked anyone who had made a direct-to-consumer DNA test to upload a copy so that law enforcement could spot any connections to DNA found at crime scenes.

Finally, GEDmatch, the online public-access database used in the Golden State Killer case, changed their Terms of Service. Since May 2019 users have to explicitly opt in for their DNA profiles to be included in law enforcement searches to identify remains and perpetrators of violent crimes, defined as homicides or sexual assaults (Kennett, 2019; Moore, 2016). Although it is acceptable to expect that users of such databases are currently informed about its wide implications, such policies do not secure consent from the biological relatives that might, unexpectedly, become implicated into a criminal investigation.

Therefore, the different approaches taken by different companies and other online resources mobilized for long-range familial searches exemplify the lack of restrictions and constraints currently under place to balance the right of individuals to genetic privacy against the desire to apprehend criminals (Murphy, 2018). In addition to such a scenario, another layer of this lack of governance and oversight is linked to the inexistence of accreditation, professionalization and accountability for genealogists. As a result, individuals with very different degrees of expertise might be involved in such procedures, which poses severe ethical issues (Kennett, 2019).

Within such a complex scenario, it is clear that while familial searching in forensic DNA databases is framed by a series of inclusion and exclusion criteria that impose some safeguards in terms of genetic privacy (Granja \&

\footnotetext{
${ }^{9}$ https://www.technologyreview.com/the-download/613232/help-us-catch-killers-isnow-the-new-advertising-angle-for-dna-companies/ (last accessed on 29 April 2019).
} 
Machado, 2019; Haimes, 2006; Kim et al., 2011; Murphy, 2010, 2018), private companies have extensive databases, with few restrictions and inexistent governance. Long-range familial searches in recreational DNA databases thus offer a way of circumventing long-established protocols in forensic DNA databases.

Despite such a spirited debate taking place, little is yet known about how the public perceives such new avenues of criminal investigation. In the aftermath of the Golden State Killer criminal case, a survey of 1587 US residents found that the majority of respondents supported police searches of genetic websites that identify genetic relatives $(79 \%)$ and the disclosure of direct-to-consumer genetic testing customer information to the police $(62 \%)$, as well as the creation of fake profiles of individuals by the police on genealogy websites $(65 \%)$. However, respondents were significantly more supportive of these activities to identify perpetrators of violent crimes, perpetrators of crimes against children and missing persons cases (Guerrini, Robinson, Petersen, \& McGuire, 2018).

Old and new debates over the use of familial searches for criminal investigation purposes therefore shed light on how we are no longer solely discussing an interaction between science and law. The advent of longrange familial searches in recreational databases puts in focus how police forces, scientific experts, private companies, media and consumers increasingly interact. Such scenario thus brings to the table issues of trust and distrust, citizens' understanding of genetic science, uncontrolled access to citizens' genetic data and expansion of affected populations. Although such uses of recreational databases are, for now, mainly restricted to the US context, this type of databases are increasingly expanding worldwide. As a result, it is possible that law enforcement agencies in other countries will consider using such investigative technique.

\section{Forensic DNA Phenotyping}

Forensic DNA phenotyping can be broadly described as a constellation of techniques ${ }^{10}$ that aims to infer externally visible physical features in humans-eye, hair and skin colour-and continental-based biogeographi-

\footnotetext{
${ }^{10}$ We use the term "constellation" to define forensic DNA phenotyping and outline the set of different genetic techniques that might be used to infer externally visible characteristicssuch as eye, skin and hair colour - as well as information about biogeographic ancestry. In addition, the use of this term also aims to highlight how such techniques can be used either jointly or separately.
} 
cal ancestry of criminal suspects, through the analysis of biological materials collected at crime scenes ${ }^{11}$ (Daniel et al., 2015; Kayser, 2015; Kayser \& de Knijff, 2011; Kayser \& Schneider, 2009). Forensic DNA phenotyping technologies have been applied in various jurisdictions in a limited number of high-profile cases (Wienroth, 2018a, p. 4) with the aim of providing intelligence for criminal investigations.

The potentialities attributed to forensic DNA phenotyping in supporting criminal investigations show its added intelligence value by generating new leads when the DNA collected from crime scenes is not registered in forensic DNA databases and/or when there are no eyewitnesses available (Kayser, 2015). ${ }^{12}$ More particularly, forensic DNA phenotyping works by inferring to which group a particular individual might belong (i.e., a group of people with blue eyes and European ancestry). Within a criminal investigation, such type of data is translated by clustering a group of people who share a set of characteristics and considering them "a suspect population" (M'charek, 2008).

The initial debate in the field of social sciences about this genetic technology has primarily focused on the socio-ethical challenges that might emerge from its use in the criminal justice system. For the purposes of this chapter, we outline three domains that have been extensively debated. The first regards the high expectations placed upon the potential of forensic DNA phenotyping. Contrary to what is often disseminated in popular media when this topic is touched upon, forensic geneticists argue that forensic DNA phenotyping tests cannot "predict" the external characteristics of a person or his/her ancestry with fool-proof certainty. Such interpretation of the potential of forensic DNA phenotyping might lead to severe miscarriages of justice. According to such professionals, forensic DNA phenotyping's potential lies in the inference of individual's phenotypic characteristics within a certain degree of probabilistic likelihood

${ }^{11}$ For the purposes of this chapter, we excluded the potential uses of this technology in the search and/or identification of missing persons.

${ }^{12}$ Legislation about the use of forensic DNA phenotyping differs widely across Europe. It is only explicitly regulated in the Netherlands (Samuel \& Prainsack, 2018a, 2018b). In other countries, legislation is either implicit or absent, which implies that it might be differently interpreted by experts and practitioners. As a result, forensic DNA phenotyping is applied in countries such as Spain and the UK and considered as forbidden in others, namely, Germany, Belgium and Austria. Nevertheless, there are ongoing debates and proposals on the regulation of forensic DNA phenotyping in both Germany and Switzerland (Samuel \& Prainsack, 2018a). 
(Samuel \& Prainsack, 2018a). These expanding high expectations are further complicated by the claims made by the company Parabon NanoLabs, which markets forensic DNA phenotyping as a technology able to produce facial composite images of potential suspects, including facial features and morphology. Claims of that kind have been extensively criticized by criminal justice stakeholders and scientific practitioners who research and work in the field of forensic DNA phenotyping (Wienroth, 2018b).

The second area of debate regarding forensic DNA phenotyping that has been receiving wide attention refers to the problematic nature of defining populations through genetics. In particular, scholars in social sciences outline the need to problematize how the genetic reinscription of race (El-Haj, 2007) might play out in the everyday practices of criminal investigations. That is, how socially constructed notions of "race" and "ethnicity" might be translated into biological characteristics and vice versa. For example, stating that the criminal suspect is possibly from "African ancestry" is probably going to be translated and materialized by law enforcement, justice stakeholders and the general public into "the suspect is probably black" (Samuel \& Prainsack, 2018a). In this sense, disclosing information related to biogeographical ancestry is a sensitive issue, as the forensic distinction of populations by continents or population groups can easily lead to inaccurate socially constructed associations between these and categories of race and ethnicity (M'charek, 2008; Vailly, 2017).

In addition, the act of revealing that a certain criminal suspect is from a racial or ethnic minority might further compound discriminatory practices against already vulnerable groups. Forensic DNA phenotyping might, thus, present a risk of renewing existing forms of stigmatization and creating new forms of racial profiling that further exacerbate the criminalization of certain groups, which are already the most affected by the actions of the criminal justice system, such as racial and ethnic minorities (M'charek, Toom, \& Prainsack, 2012).

The third area under discussion concerns the idea that forensic DNA phenotyping might be used in criminal investigations as a "biological witness" (Kayser, 2015). Such a concept encapsulates the notion that forensic DNA phenotyping techniques might overcome the limitations of information presented by eyewitness testimonies, which are perceived as fragile, pervaded with emotions, motivations, subjectivities and information gaps. When reacting to that argument, several social scientists have been outlining, on the one hand, the risks of perceiving science and technology as 
immune to social bias, and, on the other, the socially decontextualized nature of information provided by forensic DNA phenotyping, especially when directly compared with eyewitness accounts that often provide context about the events of a crime (Toom et al., 2016).

In addition to such debates about the ethical, legal and social implications of forensic DNA phenotyping, the topic has been increasingly raising interest from scholars. Richard Tutton and his colleagues have critically explored the UK Border Agency's initiative of using genetic testing to discover ancestry and geographical origins and isotope testing ${ }^{13}$ to corroborate asylum seekers' accounts of their nationality (Tutton, Hauskeller, \& Sturdy, 2014). The authors outline how such technologies deprive individuals of the right to tell their own stories by employing biological categories as a proxy for the social category of nationality (Tutton et al., 2014, p. 746) and further aggravate the criminalization of asylum applicants. Another study, by Joëlle Vailly, analysed the power relations which emerged in France in relation to forensic DNA phenotyping through an analysis of the discourses of judges and prosecutors, political officials and managers in biotechnology companies. The author shows how such power relations emerged between different social actors, according to their different connections and affiliations to ethics, politics and law (Vailly, 2017).

Another recent study has addressed the views of forensic geneticists about forensic DNA phenotyping by focusing on how scientists engage with a set of anticipatory practices (Wienroth, 2018a). Mathias Wienroth explores the promissory aspects of forensic DNA phenotyping, along with its epistemic and operational aspects-such as management of expectations, negotiation of legislative barriers and integration into existing technologies. In a different piece of work, Wienroth also analyses how forensic DNA phenotyping is entrenched in the political economy of forensic genetics, anchored in the intersection of scientific ethics, forensic practices and commercial resources. Drawing on the case of Parabon NanoLabs' DNA photo-fits, the author outlines how scientists' ethical reasoning about the development and use of forensic DNA phenotyping tackles issues of validation, epistemic transparency, science legitimacy and commercial value in ways that continuously reassert scientific primacy over commercial, legal and judicial concerns (Wienroth, 2018b).

Gabrielle Samuel and Barbara Prainsack have also recently written publications about forensic DNA phenotyping. In one of such publications

\footnotetext{
${ }^{13}$ Isotope testing analyses the way different environments may leave distinctive traces in individuals' bodies (Tutton et al., 2014, pp. 744-745).
} 
the authors address the views of actors with a professional stake in forensic DNA phenotyping about the benefits and problems associated with the prospective use of the technology. More particularly, Samuel and Prainsack show how respondents do not "view forensic DNA phenotyping as a technology with clear boundaries that 'raised' ethical issues. Instead, forensic DNA phenotyping was portrayed as a heterogeneous set of practices and material technologies that were partly shaped by ethical considerations" (Samuel \& Prainsack, 2018a, pp. 3-4), which include issues of validity, reliability and discrimination. In another publication, the authors explore how civil society stakeholders strike a balance between the potential usefulness of the use of forensic DNA phenotyping and the various ethical and social considerations (Samuel \& Prainsack, 2019).

Finally, David Skinner has addressed the topic of why race prediction within forensic DNA phenotyping is particularly problematic. The author discusses the implications of and for forensic DNA phenotyping in the context of established social structural inequalities that affect minorities in the realm of police and justice (Skinner, 2018a). Moreover, the author also frames forensic DNA phenotyping as entrenched in wider significant changes in the use of race as an object of expert knowledge in science and policy-making (Skinner, 2018b).

Despite the still-evolving controversies on forensic DNA phenotyping in several countries, further development of intelligence-focused technologies is being equated: a recent publication, for instance, argues in favour of broadening DNA-based forensic intelligence by coupling it with epigenomic lifestyle predictions to find unknown perpetrators of crimes who are not identifiable using current forensic DNA profiling (Vidaki \& Kayser, 2017,2018 ). Building upon the concept and possibilities of epigenetics (covered in Chap. 3), some forensic geneticists are thereby considering that future perspectives of forensic epigenomics might include the ability to predict smoking, drinking and drug-use habits, the type of diet followed, physical activity levels, body size/shape, geographic region of residence as well as socioeconomic status (Vidaki \& Kayser, 2017).

\section{Concluding Remarks}

This chapter aimed to critically explore the complex politics of legitimation and contestation (Skinner, 2018b) that frame the development and consolidation of DNA technologies focused on generating intelligence, such as familial searching and forensic DNA phenotyping. Such technolo- 
gies represent particularly interesting cases to question the role of forensic genetics in the governance of crime. Firstly, despite the association with notions of a "gold standard" that frames forensic science, recent and still developing technologies present ongoing issues about their usefulness, reliability and regulatory framework. Nevertheless, developers and advocates for its adoption strongly draw upon a narrative of objectivity to bolster its adoption, further development and expansion (Wienroth, 2018a). Secondly, by constructing suspicion as collective, rather than individual, such technologies also bring an additional layer to issues of discrimination. Finally, such technologies are also clearly outlining how modern science will unravel under the aegis of the market, which brings complex consequences and contingencies for human rights.

\section{REFERENCES}

Abbott, A., Butler, D., Castelvecchi, D., Cressey, D., Gibney, E., Ledford, H., ... Witze, A. (2018). 2018 in news: The science events that shaped the year. Nature. https://www.nature.com/articles/d41586-018-07685-3

Abel, S. (2018). What DNA can't tell: Problems with using genetic tests to determine the nationality of migrants. Anthropology Today, 34(6), 3-6. https://doi. org/10.1111/1467-8322.12470

Bieber, F. R., Brenner, C. H., \& Lazer, D. (2006). Finding criminals through DNA of their relatives. Human Genetics, 312, 1315-1316. https://doi. org/10.1126/science.1122655

Borry, P., Cornel, M. C., \& Howard, H. C. (2010). Where are you going, where have you been: A recent history of the direct-to-consumer genetic testing market. Journal of Community Genetics, 1(3), 101-106. https://doi.org/10.1007/ s12687-010-0023-z

Chamberlain, M. (2012). Familial DNA searching. A proponent's perspective. Criminal Justice, 27(1).

Chow-White, P., \& Duster, T. (2011). Do health and forensic DNA databases increase racial disparities? PLoS Medicine, 8(10), el001100. https://doi. org/10.1371/journal.pmed.1001100

Chow-White, P., Struve, S., Lusoli, A., Lesage, F., Saraf, N., \& Oldring, A. (2018). 'Warren Buffet is my cousin': Shaping public understanding of big data biotechnology, direct-to-consumer genomics, and 23andMe on Twitter. Information Communication and Society, 21(3), 448-464. https://doi.org/1 $0.1080 / 1369118 X .2017 .1285951$

Cole, S. (2018). Individual and collective identification in contemporary forensics. BioSocieties, 1-26. https://doi.org/10.1057/s41292-018-0142-z 
Daniel, R., Santos, C., Phillips, C., Fondevila, M., Van Oorschot, R., Carracedo, Á., ... McNevin, D. (2015). A SNaPshot of next generation sequencing for forensic SNP analysis. Forensic Science International: Genetics, 14, 50-60. https://doi.org/10.1016/j.fsigen.2014.08.013

Debus-Sherrill, S., \& Field, M. B. (2019). Familial DNA searching - An emerging forensic investigative tool. Science \& Justice, 59(1), 20-28. https://doi. org/10.1016/j.scijus.2018.07.006

Dettlaff-Kakol, A., \& Pawlowski, R. (2002). First Polish DNA “manhunt” - An application of Y-chromosome STRs. International Journal of Legal Medicine, 116(5), 289-291. https://doi.org/10.1007/s00414-002-0320-0

Duster, T. (2003). Backdoor to eugenics. New York: Routledge.

El-Haj, N. A. (2007). The genetic reinscription of race. Annual Review of Anthropology, 36(1), 283-300. https://doi.org/10.1146/annurev.anthro.34. 081804.120522

Epstein, J. (2009). "Genetic surveillance" - The Bogeyman response to familial DNA investigations. Journal of Law, Technology and Policy, 1, 141-173. https://doi.org/10.2139/ssrn.1129306

Erlich, Y., Shor, T., Pe'er, I., \& Carmi, S. (2018). Identity inference of genomic data using long-range familial searches. Science, 362(6415), 690-694. https:// doi.org/10.1126/science.aau4832

Flaus, A. (2013). Familial searches and the New Zealand DNA profile databank: The thin edge of the genetic wedge? University of Otago. Retrieved from http:// www.otago.ac.nz/law/research/journals/otago065282.pdf

Gabel, J. D. (2010). Probable cause from probable bonds: A genetic tattle tale based on familial DNA. Hastings Women's Law Journal, 21(3), 3-58. Retrieved from http://ssrn.com/abstract=1495128

García, Ó., Crespillo, M., \& Yurrebaso, I. (2017). Suspects identification through "familial searching" in DNA databases of criminal interest. Social, ethical and scientific implications. Spanish Journal of Legal Medicine, 43(1), 26-34. https://doi.org/10.1016/j.remle.2017.02.002

Granja, R., \& Machado, H. (2019). Ethical controversies of familial searching: The views of stakeholders in the United Kingdom and in Poland. Science, Technology, \& Human Values, 44(6), 1068-1092. https://doi. org/10.1177/0162243919828219

Greely, H. T., Riordan, D. P., Garrison, N. A., \& Mountain, J. L. (2006). Family ties: The use of DNA offender databases to catch offenders' kin. Journal of Law, Medicine of Ethics, 34(2), 248-262. https://doi.org/10.1111/ j.1748-720X.2006.00031.x

Greytak, E. M., Moore, C., \& Armentrout, S. L. (2019). Genetic genealogy for cold case and active investigations. Forensic Science International: Genetics, 299, 103-113. https://doi.org/10.1016/j.forsciint.2019.03.039 
Grimm, D. J. (2007). The demographics of genetic surveillance: Familial DNA testing and the Hispanic community. Columbia Law Review, 107(5), 1164-1194.

Guerrini, C. J., Robinson, J. O., Petersen, D., \& McGuire, A. L. (2018). Should police have access to genetic genealogy databases? Capturing the Golden State Killer and other criminals using a controversial new forensic technique. PLoS Biology, 16(10), e2006906. https://doi.org/10.1371/journal.pbio.2006906

Haimes, E. (2006). Social and ethical issues in the use of familial searching in forensic investigations: Insights from family and kinship studies. Journal of Law, Medicine \& Ethics, 34(2), 263-276. https://doi.org/10.1111/ j.1748-720X.2006.00032.x

Holes, P. (2019). Barbara Rae-Venter. Time 100 Most Influential People 2019. Times. https://time.com/collection/100-most-influential-people-2019/ $5567712 /$ barbara-rae-venter/

Horowitz, A. L., Saperstein, A., Little, J., Maiers, M., \& Hollenbach, J. A. (2019). Consumer (dis-)interest in genetic ancestry testing: The roles of race, immigration, and ancestral certainty. New Genetics and Society, 1-30. https://doi.org/ $10.1080 / 14636778.2018 .1562327$

Joh, E. E. (2006). Reclaiming "Abandoned" DNA: The fourth amendment and genetic privacy. Northwestern University Law Review, 100(2), 857-884.

Jones, T. (2015, January). The murder that has obsessed Italy. The Guardian.

Kayser, M. (2015). Forensic DNA phenotyping: Predicting human appearance from crime scene material for investigative purposes. Forensic Science International: Genetics, 18, 33-48. https://doi.org/10.1016/j.fsigen.2015. 02.003

Kayser, M., \& de Knijff, P. (2011). Improving human forensics through advances in genetics, genomics and molecular biology. Nature Reviews Genetics, 12(3), 179-192. https://doi.org/10.1038/nrg2952

Kayser, M., \& Schneider, P. (2009). DNA-based prediction of human externally visible characteristics in forensics: Motivations, scientific challenges, and ethical considerations. Forensic Science International: Genetics, 3(3), 154-161. https://doi.org/10.1016/j.fsigen.2009.01.012

Kennett, D. (2019). Using genetic genealogy in missing persons cases and to develop suspect leads in violent crimes. Forensic Science International: Genetics, 301, 107-117. https://doi.org/10.1016/j.forsciint.2019.05.016

Kim, J., Mammo, D., Siegel, M., \& Katsanis, S. (2011). Policy implications for familial searching. Investigative Genetics, 2(1), 1-22. https://doi.org/10. 1186/2041-2223-2-22

Lazer, D. (2008). Searching the family tree for suspects: Ethical and implementation issues in the familial searching of DNA databases. Taubman Center Policy Briefs, (March), 1-8. 
M'charek, A. (2008). Silent witness, articulate collective: DNA evidence and the inference of visible traits. Bioethics, 22(9), 519-528. https://doi.org/10. $1111 / j .1467-8519.2008 .00699 . x$

M'charek, A., Toom, V., \& Prainsack, B. (2012). Bracketing off population does not advance ethical reflection on EVCs: A reply to Kayser and Schneider. Forensic Science International: Genetics, 6, el6-e17. https://doi. org/10.1016/j.fsigen.2010.12.012

Maguire, C., McCallum, L. L., Storey, C., \& Whitaker, J. (2014). Familial searching: A specialist forensic DNA profiling service utilising the National DNA Database ${ }^{\circledR}$ to identify unknown offenders via their relatives-The UK experience. Forensic Science International: Genetics, 8(1), 1-9. https://doi.org/10. 1016/j.fsigen.2013.07.004

Moore, C. (2016). The history of genetic genealogy and unknown parentage research: An insider's view. Journal of Genetic Genealogy, 8(1), 35-37.

Murphy, E. (2010). Relative doubt: Familial searches of DNA databases. Michigan Law Review, 109(3), 291-348. https://repository.law.umich.edu/cgi/viewcontent.cgi?article $=1169 \&$ context $=\mathrm{mlr}$

Murphy, E. (2018). Law and policy oversight of familial searches in recreational genealogy databases. Forensic Science International: Genetics, 292, e5-e9. https://doi.org/10.1016/J.FORSCIINT.2018.08.027

Nuffield Council on Bioethics. (2007). The forensic use of bioinformation: Ethical issues. London. https://nuffieldbioethics.org/assets/pdfs/The-forensic-useof-bioinformation-ethical-issues.pdf

Prainsack, B. (2010). Key issues in DNA profiling and databasing: Implications for governance. In R. Hindmarsh \& B. Prainsack (Eds.), Genetic suspects: Global governance of forensic DNA profiling and databasing (pp. 153-174). Cambridge: Cambridge University Press.

Samuel, G., \& Prainsack, B. (2018a). Forensic DNA phenotyping in Europe: views "on the ground" from those who have a professional stake in the technology. New Genetics and Society, 1-23. https://doi.org/10.1080/14636778. 2018.1549984

Samuel, G., \& Prainsack, B. (2018b). The regulatory landscape of forensic DNA phenotyping in Europe. VISAGE. Retrieved from http://www.visage-h2020. eu/Report_regulatory_landscape_FDP_in_Europe2.pdf

Samuel, G., \& Prainsack, B. (2019). Civil society stakeholder views on forensic DNA phenotyping: Balancing risks and benefits. Forensic Science International: Genetics, 43, 102157. https://doi.org/10.1016/j.fsigen.2019.102157

Skinner, D. (2013). "The NDNAD has no ability in itself to be discriminatory": Ethnicity and the governance of the UK National DNA Database. Sociology, 47(5), 976-992. https://doi.org/10.1177/0038038513493539

Skinner, D. (2018a). Forensic genetics and the prediction of race: What is the problem? BioSocieties, 1-21. https://doi.org/10.1057/s41292-018-0141-0 
Skinner, D. (2018b). Race, racism and identification in the era of technosecurity. Science as Culture, 1-23. https://doi.org/10.1080/09505431.2018.1523887

Suter, S. M. (2010). All in the family: Privacy and DNA familial searching. Harvard Journal of Law \& Technology, 23(2), 309-399.

Thomas, L. (2006). Nothing to hide, something to fear?: The use of partial DNA matching in criminal investigations. Journal of Law, Information and Science, $17,72-93$.

Toom, V., Wienroth, M., M'charek, A., Prainsack, B., Williams, R., Duster, T., ... Murphy, E. (2016). Approaching ethical, legal and social issues of emerging forensic DNA phenotyping (FDP) technologies comprehensively: Reply to 'Forensic DNA phenotyping: Predicting human appearance from crime scene material for investigative purposes' by Manfred Kayser. Forensic Science International: Genetics, 22, el-e4. https://doi.org/10.1016/j.fsigen.2016. 01.010

Tutton, R., Hauskeller, C., \& Sturdy, S. (2014). Suspect technologies: Forensic testing of asylum seekers at the UK border. Ethnic and Racial Studies, 37(5), 738-752. https://doi.org/10.1080/01419870.2013.870667

Vailly, J. (2017). The politics of suspects' geo-genetic origin in France: The conditions, expression, and effects of problematisation. BioSocieties, 12(1), 66-88. https://doi.org/10.1057/s41292-016-0028-x

Vidaki, A., \& Kayser, M. (2017). From forensic epigenetics to forensic epigenomics: Broadening DNA investigative intelligence. Genome Biology, 18(1), 238. https://doi.org/10.1186/s13059-017-1373-1

Vidaki, A., \& Kayser, M. (2018). Recent progress, methods and perspectives in forensic epigenetics. Forensic Science International: Genetics, 37(July), 180195. https://doi.org/10.1016/j.fsigen.2018.08.008

Wienroth, M. (2018a). Governing anticipatory technology practices. Forensic DNA phenotyping and the forensic genetics community in Europe. New Genetics and Society, 1-16. https://doi.org/10.1080/14636778.2018. 1469975

Wienroth, M. (2018b). Socio-technical disagreements as ethical fora: Parabon NanoLab's forensic DNA Snapshot ${ }^{\mathrm{TM}}$ service at the intersection of discourses around robust science, technology validation, and commerce. BioSocieties. https://doi.org/10.1057/s41292-018-0138-8

Williams, R., \& Johnson, P. (2004). Circuits of surveillance. Surveillance \& Society, 2(1), 1-14. https://ojs.library.queensu.ca/index.php/surveillance-and-society/article/view/3324

Williams, R., \& Johnson, P. (2006). Inclusiveness, effectiveness and intrusiveness: Issues in the developing uses of DNA profiling in support of criminal investigations. Journal of Law, Medicine \& Ethics, 33(3), 545-558. https://doi. org/10.1111/j.1748-720X.2005.tb00517.x 
Open Access This chapter is licensed under the terms of the Creative Commons Attribution 4.0 International License (http://creativecommons.org/licenses/ by $/ 4.0 /$ ), which permits use, sharing, adaptation, distribution and reproduction in any medium or format, as long as you give appropriate credit to the original author(s) and the source, provide a link to the Creative Commons licence and indicate if changes were made.

The images or other third party material in this chapter are included in the chapter's Creative Commons licence, unless indicated otherwise in a credit line to the material. If material is not included in the chapter's Creative Commons licence and your intended use is not permitted by statutory regulation or exceeds the permitted use, you will need to obtain permission directly from the copyright holder.

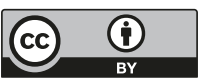

